\title{
Boarding of two ports by transthoracical route without endotracheal intubation. A line of inquiry
}

\author{
Francisco P. Navarro-Reynoso*, Benito Vargas-Abrego, Miguel Ferretti-Cruz, Pablo Alvarez-Maldonado, \\ and Raul Cicero-Sabido \\ Pneumology and Thorax Surgery Service, General Hospital of Mexico, Eduardo Liceaga, Mexico City, Mexico
}

\begin{abstract}
The approach to mediastinal injuries is one of the most exciting procedures for the chest surgeon. Lateral thoracotomy or sternotomy is usually used, although there are other procedures. With the development of thoracoscopic surgery implemented by Jacoveus, it has been perfected above all with better equipment and technological implements, although it has become clear to our work group in which cases it should be used and in which cases it should not. In some mediastinal lesions the endoscopic approach is possible and not feasible in others. In this work group, we have been able to implement the two-port surgical approach for the resection of some mediastinal lesions, as in this case, which is already in addition to the technique proposed in this Service.
\end{abstract}

Keywords: Thoracoscopy. Mediastinal injuries. Mediastinal cysts.

\section{Introduction}

The mediastinum is the anatomical compartment located in the center of the chest. Limited by both pleuras on their side faces, sternum and chondrocostal joints at the front and back by the anterior areas of the vertebral bodies and ribs. The lower limit is given by the diaphragm and the upper limit by the upper chest narrow. The anatomical division and the structures they contain are described in Table 1.

\section{Case Report}

32-year-old male patient, Bachelor of Computer Science who goes to medical review at the company where he works for dizziness, cardiac arrhythmia that increased when lying left, face up and sitting so he is prescribed telmisartan 40 mgs., every 24 hrs. The Chest x-ray as a finding mediastinal widening of right dominance and based on this he was taken chest CT scan where a mediastinal cystic injury was demonstrated so it was proposed that it should be resection (Figs. 1-3).

It was programmed for chest surgery through two ports, with the patient sedated in the seated position, without being intubated with nasal catheter at 3 liters per minute, it was proceeded to infiltative with local anesthetic combining $9 \mathrm{mls}$., ropivacaine at 7.5\%, 9 mls., of xylocaine $2 \%$ with epinephrine and $2 \mathrm{mls}$. of sodium bicarbonate, $2 \mathrm{mls}$. for each intercostal nerve in the five and six intercostal space. Skin is inserted in five intercostal space is inserted chestscope observed which was punctured, to empty into its contents, pull it with a Gasper Clamp and cut almost completely leaving only a small part to attached to the mediastinum to vascular structures. He was left with a Nelaton 26 tube and the next day after chest $x$-ray, which showed total pulmonary re-expansion and no pleural effusion, the pleural tube was removed.

\section{Correspondence:}

*Francisco P. Navarro-Reynoso

E-mail: franciscopnavarro@yahoo.com.mx

NC-ND license (http://creativecommons.org/licenses/by-nc-nd/4.0/)
Date of reception: $26-05-2021$

Date of acceptance: 18-11-2021

DOI: 10.24875/HGMX.21000038
Available online: 07-03-2022 Rev Med Hosp Gen Mex. 2022;85(1):55-58 www.hospitalgeneral.mx 
Table 1. Mediastinal anatomical division with its limits and structures containing

\begin{tabular}{|l|l|l|}
\hline Division & Limits & Structures \\
\hline Anterior & $\begin{array}{l}\text { Anterior: posterior sternum, Posterior: anterior } \\
\text { pericardium margin, aorta y brachycephalic. }\end{array}$ & $\begin{array}{l}\text { Timus } \\
\text { Linfatic nodules } \\
\text { Grease } \\
\text { Internal Breast vessels }\end{array}$ \\
\hline Medium & $\begin{array}{l}\text { Anterior: posterior margin of the division anterior } \\
\text { subsegment. } \\
\text { Posterior: anterior margin of posterior division. }\end{array}$ & $\begin{array}{l}\text { Heart and pericardium } \\
\text { Aorta ascending and y transverse. Brachyphthalic } \\
\text { vessels. } \\
\text { Upper and lower cava vessels. } \\
\text { Mains Pulmonary vessels and Bronchus. } \\
\text { Lymph nodes and grease }\end{array}$ \\
\hline Posterior & $\begin{array}{l}\text { Anterior: pericadium. Posterior: pre-vertebral fascia and } \\
\text { anterior longitudinal ligament. }\end{array}$ & $\begin{array}{l}\text { Descending Aorta } \\
\text { Esophagus } \\
\text { Chest conduit } \\
\text { Acigos and hemiacigos vein, autonomic nerves, Lymph } \\
\text { nodes, grease. }\end{array}$ \\
\hline
\end{tabular}

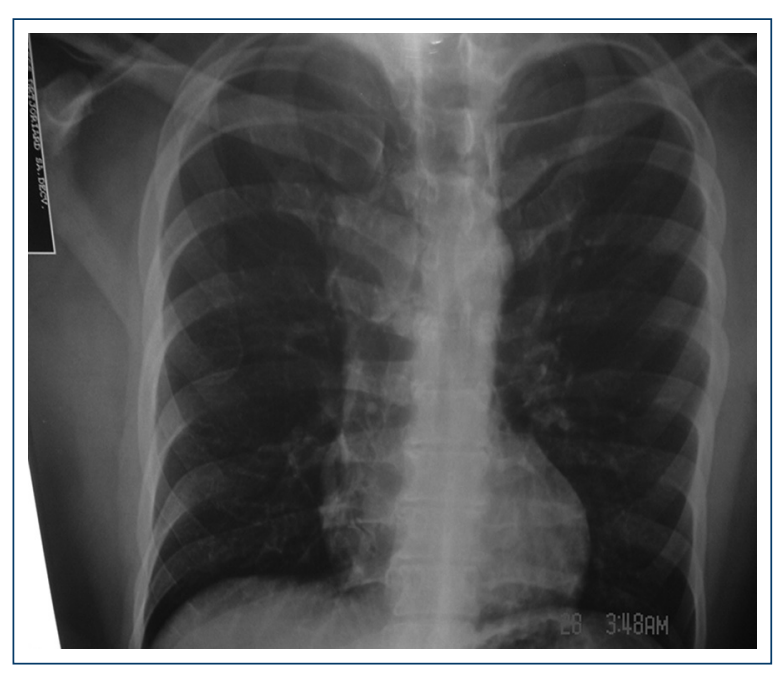

Figure 1. Chest $\mathrm{RX}$ with mediastinal widening with rigth dominance.

\section{Discussion}

Within mediastinum tumors, mediastinal cysts make up $20 \%$ of the masses affecting that space ${ }^{1}$. They usually occur as a mass in asymptomatic patients, identified in a chest screening $\mathrm{x}$-ray, or with symptoms generated by the condition to the different mediastinal structures (hypoxia, facial swelling and acute respiratory failure $)^{2}$. In the case presented the patient had symptoms when changing position, which caused the patient to go to the doctor.

The most common mediastinal tumors in adults are: thymo and thymic cysts $(26.5 \%)$, neurogenic tumors $(20 \%)$, other cysts $(16.1 \%)$, germ cell tumors $(13.8 \%)$

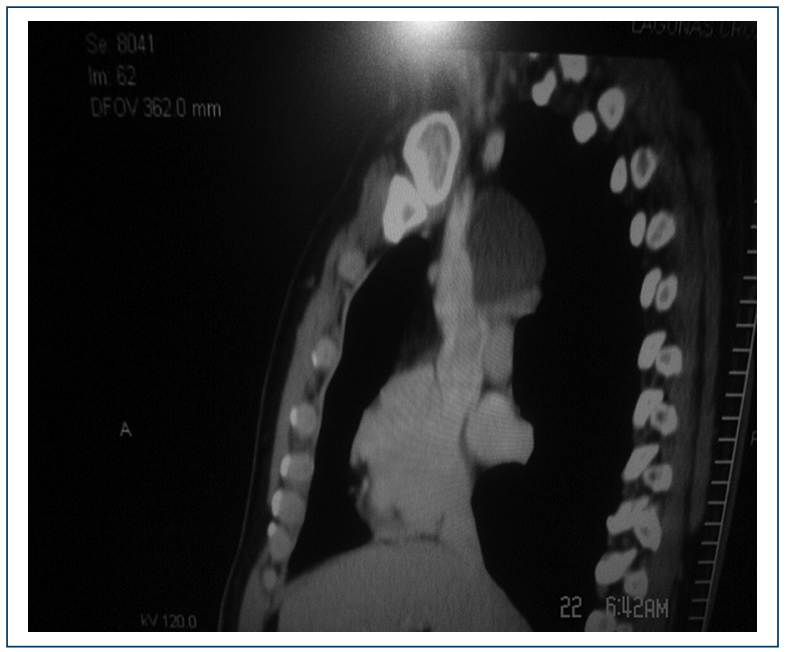

Figure 2. Chest Tomografy. Mediastinal cystic between braquiocefalic arterial trunk and superior vena cava.

lymphomas $(12.7 \%)^{1}$ (Table 2). In a series of 1814 cases of chest tumors reported at a third-level University Hospital in Mexico City, a ratio of $50.8 \%$ was made up of Bronchogenic Carcinoma, Pleuropulmonary Metastasis (39.1\%), Mediastinal Tumors (7.3\%), Pleura Tumors $(1.9 \%)$ chest wall tumors $(0.5 \%)^{3}$.

Mediastinal cysts are a heterogeneous group of neoplastic, congenital and inflammatory lesions, rare in clinical practice and a number of them are found casually during a radiological examination by other indications ${ }^{3}$. They occur in both adult and child populations, and their classification is based on the cause ${ }^{3,4}$. In a series of 105 patients with mediastinal tumors at a University Hospital in Turkey, 34 cases were found that 
accounted for $33 \%$ of all tumors, with $94 \%$ congenital origin and $4 \%$ hydatid disease ${ }^{5,6}$, the latter perhaps

Table 2. Classification of mediastinun tumors

\begin{tabular}{|c|c|}
\hline $\begin{array}{l}\text { Thymoma } \\
\text { Benig } \\
\text { Malignant }\end{array}$ & $\begin{array}{l}\text { Lymphoma } \\
\text { Hodgkin×s disease } \\
\text { Linfoblastic Lymphoma } \\
\text { Large Cell Lymphoma }\end{array}$ \\
\hline $\begin{array}{l}\text { Germ cell tumors } \\
\text { Teratodermoid (benign/ } \\
\text { malignant) } \\
\text { Seminoma } \\
\text { No seminomatous: } \\
\text { Embryonic } \\
\text { Choriocarcinoma } \\
\text { Endodermic }\end{array}$ & $\begin{array}{l}\text { Primary Carcinomas } \\
\text { Mesenchymatous tumors } \\
\text { Fibroid/fibrosarcoma } \\
\text { Lipoma/liposarcoma } \\
\text { Leiomioma/leiomiosarcoma } \\
\text { Rhabdomyosarcoma } \\
\text { Xantogranuloma } \\
\text { Myxoma } \\
\text { Mesothelioma } \\
\text { Hemanioma } \\
\text { Hemangioendotelioma } \\
\text { Hemangiopericitoma } \\
\text { Lynfangioma } \\
\text { Lynfangioperycitoma } \\
\text { Endocrine tumors } \\
\text { Intratoracic Thyroid } \\
\text { Adenoma/carcinoma } \\
\text { parathyroid } \\
\text { Carcinoid }\end{array}$ \\
\hline $\begin{array}{l}\text { Cystic } \\
\text { Broncogenic } \\
\text { Pericárdial } \\
\text { Entéric } \\
\text { Thymic } \\
\text { Chest duct } \\
\text { No-specífic }\end{array}$ & $\begin{array}{l}\text { Giant lymph node } \\
\text { Castelman×s Disease }\end{array}$ \\
\hline Condroma & Extramedullary Hematopoiesis \\
\hline $\begin{array}{l}\text { Neurogen Tumors } \\
\text { Neurofibroma } \\
\text { Neurilemoma } \\
\text { Paraganglioma } \\
\text { Ganglioneuroma } \\
\text { Neuroblastoma } \\
\text { Chemodectoma } \\
\text { Neurosarcoma }\end{array}$ & \\
\hline
\end{tabular}

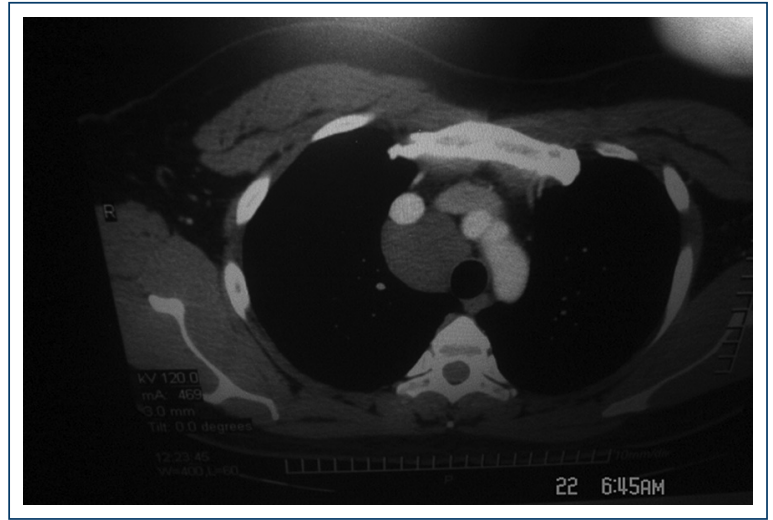

Figure 3. Chest tomografy. Cystic mediastinal image right dominance.
Table 3. Cyst Mediastinic Classification by location

\begin{tabular}{l|l|l} 
Anterior & Medium & Posterior \\
Mediastinum & Mediastinum & Mediastinum \\
Cystic hygromas & Cystic & Gastroenteriic \\
Cystic Tymus: & Pericardic pleura & Cystic and \\
Congenic and & and pericardic & duplications \\
acquired & Bromchogenic & Neuroenteric cystic \\
& Cystic &
\end{tabular}

because of the living conditions they have in that area of the world.

Primary mediastinal cysts probably correspond to embryonic developmental abnormalities in the proximal intestine region, at the time of separation of esophageal and pulmonary buds. They are characterized by the organ of origin and can be bronchogenic, pericardial, enteric, timid or nonspecific (Tables 3 and 4) 7,8 .

The bronchogenic cyst is a part of the tracheobronchial tree that is separated during the bronchial branching process and does not continue its development. Commonly rounded shape, thin and unique wall. It contains serous-mucous liquid, a few cases open to bronchi showing a hydro-air level inside ${ }^{9}$.

Followed in order of frequency, after bronchogenic cysts are pericardial cysts, which are located at the cardiophrenic angle, usually on the right side $(70 \%)$, which may have communication with the pericardium and usually contain clear liquid, are smooth-edged and a water-like cystic liquid attenuation. Fine needle aspiration and routine follow-up are sufficient for handling ${ }^{3-7}$.

Enteric or duplication cysts derive from the anterior primitive intestine, which are usually attached to the esophagus and cause compression symptoms ${ }^{7,8,9}$.

Clinical presentation and diagnosis is sometimes complex, as symptoms lack specificity and most are mainly due to compression of adjacent structures, as was the case in this article. Dysphagia, weight loss, anorexia and cough make you think of underlying malignancies ${ }^{5,10-15}$.

Chest tomography is the technique of choice in the diagnosis of mediastinum tumors.

Cystic lesions generally show attenuation close to or greater than water density, solid lesions have greater attenuations than water, treatment in most cases tends to be complete resection or drainage of the injury ${ }^{16,17}$.

In the management of some lesions of the mediastinum it is possible to do so with the thorachoscopy technique and these, with the variant of two ports without intubating the patient, with which it is possible to 
Table 4. Classification of common mediastinum tumors by anatomical compartment

\begin{tabular}{|l|l|}
\hline Anterior Mediastinum & Medium mediastinum \\
Thymic tumors & Adenopathies: benign or malignant \\
Lymphomas & Cysts pleuro-pericardic \\
Germ cell tumors & Bronchogenic Cystis \\
Intrathoracic thyroid & \\
Intrathiracic parathyroid adenoma & \\
Mesenquimal tumors: lipoma, & \\
hemangioma. &
\end{tabular}

Posterior Mediastinum Neuogenic Tumors Cysts/duplicatons hiatal or parahyatal esophageal hernial or gastroenteric. Esophageal diverticulosis Abscesses vertebral or paravertebral. Meningoceles Vertebral Metastasis Lung Abductions address the chest, visualize the mediastinum and resectiont the lesions found, so we could say that it can be performed not in large injuries but in small lesions with the non-intubated patient, in well-selected cases or in patients at high surgical risk from general anesthesia and endotracheal intubation.

The pleurotomy tube is left to be able to observe the liquid or air outlet after the procedure, and may be removed the next day if the lung is inflated and there is no other complication ${ }^{18}$.

\section{Acknowledgements}

To Lic. Helena Carolina Navarro Silva, for her help in preparing the manuscript.

\section{Funding}

We do not receive any type of financing.

\section{Conflict of interests}

The authors declare that they have no conflict of interest.

\section{Ethical responsibilities}

Protection of humans and animals. The authors declare that they did not experiment on humans or animals for this study.

Confidentiality of data. The authors declare that the data is not protected by the center where the patient was operated on.

Right to privacy and informed consent. The authors obtained in writing the informed consent of the patient mentioned in this article for the performance of the procedures. These are in the patient file duly signed.

\section{References}

1. Donahue J.M., and Nichols F.C.: Primary mediastinal tumors and cysts and diagnostic investigation of mediastinal masses. In Shields T.W., LoCicero J., and Reed C.E. (eds): General thoracic surgery, ed 7. Philadelphia: Lippincott Williams \& Wilkins, 2009. pp. 2195-2199

2. Whitten C. R. Khan S., Munneke G. J., et al: A diagnostic approach to mediastinal abnormalities. Radiographics 2007; 27: pp. 657-671.

3. Navarro-Reynoso FP, Lorenzo-Silva JM. Tratamiento quirúrgico de los tumores gigantes del mediastino. Gac. Méd. Mex. Vol. 137 No 2, 2001.

4. Cohen AJ, Thompson L, Edwards FH, Bellamy RF. Primary cysts and tumors of the mediastinum. Ann Thorac Surg. 1991; 51:78-86.

5. Gürsoy S, Ozturk A., Ucvet A., Emin Erbaycu A. Lesiones quísticas primarias y benignas del mediastino en el adulto: espectro clínico y tratamiento quirúrgico. Arch Bronconeumol. 2009;45(8):371-375.

6. Takeda S, Miyoshi S, Minami M, Ohta M, Masaoka A, Matsuda H. Clinical spectrum of mediastinal cysts. Chest. 2003; 124:125-32

7. Donahue J.M., and Nichols F.C.: Primary mediastinal tumors and cysts and diagnostic investigation of mediastinal masses. In Shields T.W., LoCicero J., and Reed C.E. (eds): General thoracic surgery, ed 7. Philadelphia: Lippincott Williams \& Wilkins, 2009. pp. 2195-2199.

8. Maier H.C.: Bronchogenic cysts of the mediastinum. Ann Surg 1948; 127 : pp. 476-502.

9. Marquez-Perez, FL., Gutiérrez-Lara JL. Malformaciones y alteraciones del desarrollo del aparato respiratorio. Neumologia clínica, Cap 98, 832-840.

10. Proto AV. Mediastinal anatomy: emphasis on conventional images with anatomic and computed tomographic correlations. J Thorac Imaging. 1987; 2:1-48.

11. Heitzman ER. The Mediastinum: radiologic correlations with anatomy and pathology. $2^{\text {nd }}$. Ed. 1988. Soft cover reprint of the original $2^{\text {nd }}$. Ed. 1988. edition. Berlin, Heidelberg: Springer; 2012. 355.

12. Coche EE, Ghaye B, Mey JD, Duyck P. Comparative interpretation of CT and standard radiography of the chest. Springer Science \& Business Media; 2011.

13. Webb WR, Higgins CB. Thoracic imaging: pulmonary and cardiovascular radiology. Lippincott Williams \& Wilkins; 2010.

14. Hansell DM. Imaging of Diseases of the Chest: Expert Consult Online and Print. $5^{\text {th }}$. Ed. Edinburgh: Mosby; 2009.

15. Lai V, Tsang WK, Chan WC, Yeung TW. Diagnostic accuracy of mediastinal width measurement on posteroanterior and anteroposterior chest radiographs in the depiction of acute non-traumatic thoracic aortic dissection. Emerg Radiol. 2012; 19: 309-15.

16. Campo-Cañaveral de la Cruz JL., Gamez-Garcia AP. Tumores y quistes del mediastino. Neumologia clínica, Capitulo 87, 726-732.

17. Yeung MY, Gasser B, Gangi A, Bogorin A, Charneau D, Wihlm JM. Imaging of cystic masses of the mediastinum. Radiographics. 2002; 22:79-93.

18. Vargas-Abrego B, Ramos-Hernandez CR., Carrillo-Torres $O$., Martínez RD, Argot YL. Thoracoscopic mediastinal exploration with local anesthesia. First case at the Hospital General de México. Rev Med Hosp Gen Méx. 2016;79(4):206-209. 